\title{
ANTIBACTERIAL ACTIVITY OF FRUIT BANANA STONE AND MECHANISM
}

\author{
PANAL SITORUS, DWI SURYANTO, HEPNI*
}

Department of Pharmaceutical Biology, Faculty of Pharmacy, Universitas Sumatera Utara, Medan, Indonesia. E-mail: hepni.bagariang89@gmail.com

Received: 12 October 2017, Revised: 05 February 2018 and Accepted: 14 February 2018

\section{ABSTRACT}

Objective: The purpose of this study was to determine the strength of antibacterial activity of the fraction of banana stone and its mechanism.

Methods: The antibacterial activity test was performed using the diffusion method by measuring the diameter of the clear zone around the disc paper.

Results: The results of antibacterial activity test showed that ethyl acetate fraction was more effective against bacterium Staphylococcus aureus, Staphylococcus epidermidis, and Propionibacterium acnes compared to n-hexane fraction.

Conclusion: The resulting cellular metabolite leak showed that cell leakage in the three bacteria due to ethyl acetate fraction had leaked more protein than nucleic acid, while the leakage of more dissolved $\mathrm{K}+$ ion than $\mathrm{Ca} 2+$ ions.

Keywords: Banana stone, Antibacterial, Mechanism.

(C) 2018 The Authors. Published by Innovare Academic Sciences Pvt Ltd. This is an open access article under the CC BY license (http://creativecommons. org/licenses/by/4. 0/) DOI: http://dx.doi.org/10.22159/ajpcr.2018.v11s1.26598

\section{INTRODUCTION}

Banana stone (Moses balbisiana Colla) belongs to the family of Musaceae, part of which is used as traditional medicine that is fruit and banana cob, fruit contains chemical compound catechin [1]. The commonly used banana fruit is a creamy fruit; the skin is green and cannot be peeled without a knife. Young fruit flesh has blackish-brown seed [1].

Based on the characterization of banana simplicia stone obtained moisture content $7.99 \%$, water soluble sari content $17,59 \%$, soluble extract in ethanol $7,86 \%$, total ash content $0,09 \%$, whereas phytochemical screening result of simplicia and ethanol extract of banana stone found the content of steroid/triterpenoid compound, glycosides, flavonoids, saponins, and tannins. The banana stone ethanol extract has antibacterial activity against Gram-positive bacteria Streptococcus mutans and Gram-negative bacteria Escherichia coli and Salmonella typhimurium, and the result of inhibiting studies is Gram-positive bacteria.

The result of antibacterial activity test showed that banana ethanol extract could inhibit the growth of Staphylococcus aureus bacteria at a concentration of $300 \mathrm{mg} / \mathrm{ml}$ with effective drag diameter of 14 and $63 \mathrm{~mm}$ and Streptococcus mutans bacteria at concentrations of $70 \mathrm{mg} / \mathrm{ml}$ with effective inhibitory concentration of extract.

The minimum inhibitory concentration of ethanol extract can inhibit the growth of $S$. aureus (SA) bacteria at a concentration of $10 \mathrm{mg} / \mathrm{ml}$ with an inhibitory diameter of $9.00 \mathrm{~mm}$ and $S$. mutans bacteria at a concentration of $10 \mathrm{mg} / \mathrm{ml}$ with an inhibitory diameter of 11 and $25 \mathrm{~mm}$ [2].

Based on the above description, the researchers conducted further testing of banana stone extract made by maceration then in fraction with n-hexane and ethyl acetate solvent, then tested the bacterial activity by diffusion method to obtain the inhibitory diameter using a variety of test bacteria, i.e. SA ATCC 25923, Staphylococcus epidermidis ATCC 25924 (SE), Propionibacterium acnes (PA) and determine the working mechanism of bananas as bactericidal such as testing the leakage of bacterial cell membranes, i.e., leakage analysis of proteins with ultraviolet visible and analysis of metal leakage using atomic absorption spectrometer (AAS).

\section{METHODS}

\section{Sample collection}

The samples used were banana stone (M. balbisiana Colla) obtained in Hamparan Perak Village, Deli Serdang Regency, North Sumatra province. Sampling is done purposively that is without comparing with the same plant from other area.

\section{Identification of samples}

Plant identification was conducted at the center for biological research and development, LIPI, Cibinong, Bogor.

\section{Sample processing}

The fruit of banana stone cleaned from dirt by washing under running water until clean and drained, then weighed wet weight, then removed the banana stone and sliced, and then dried in a drying cupboard at a temperature of $40-50^{\circ} \mathrm{C}$. Banana fruit is considered dry when it is fragile, the weighed dry weight. The sample is then powdered using a blender and then stored in a plastic container in a place that is protected from light before use.

Preparations of banana stone ethanol extract become N-Hexane fraction and ethyl acetate.

The powder of simplicia is put into a closed container of $1 \mathrm{~kg}$, added $7.5 \mathrm{~L}$ of technical ethanol and then the container was closed and left for 5 days shielded from light while frequently stirred, then filtered and pulp rinsed back with $2.5 \mathrm{~L}$ of technical ethanol. The macerate is accommodated on a dark bottle, left in a cool place, and protected from light for 2 days then filtered. The extract was concentrated using a rotary evaporator and dried with a freeze dryer. The ethanol extract yield was fractionated by liquids using n-hexane, ethyl acetate, and distilled water solvents. The ethanol extract is inserted in a separating funnel with a mixture of n-hexane:water while being shaken, repeated 3 times until the n-hexane fraction did not give a positive result on the Liebermann-Burchard rectification. The extract was further fractionated with ethyl acetate until it gave no positive reaction to iron (III) chloride $1 \%$. The result was obtained n-hexane fraction, ethyl acetate fraction, and water fraction, and the concentrated extract obtained was used for further tests [3].

\section{Sterilization equipment}

Sterilization tools used include

Tools made of glass wrapped with parchment paper and sterilized using the oven at $170^{\circ} \mathrm{C}$ for $1 \mathrm{~h}$. Other types of equipment include disc 
paper, sterilized medium in autoclave at $121^{\circ} \mathrm{C}$ for $15 \mathrm{~min}$. Needle ose and tweezers sterilized by burning on Bunsen lamp. Before starting the area around, the work is sprayed with ethanol $70 \%$ and left for $15 \mathrm{~min}$ before use. The table is cleaned of dust and wiped with disinfectant [4].

Preparation of media

Preparation of nutrient for composition:

$\begin{array}{ll}\text { Beef extract } & 3.0 \mathrm{~g} \\ \text { Peptone } & 5.0 \mathrm{~g} \\ \text { Agar } & 15.0 \mathrm{~g}\end{array}$

Method:

Weighed as much as $23 \mathrm{~g}$ of nutrient powder so that then suspended in Erlenmeyer with distilled water is added bit by bit up to $1000 \mathrm{ml}$, heated to boiling while stirring constantly until the soluble material is perfect and clear. Cover Erlenmeyer with cotton lined with aluminum foil, then sterilize into autoclave at a temperature of $121^{\circ} \mathrm{C}$ at $2 \mathrm{~atm}$ for 15 minutes [5].

\section{Making mueller-hinton agar (MHA)}

Composition:

$\begin{array}{ll}\text { Beef infusion from } & 300 \mathrm{~g} \\ \text { Casein hydrolysate } & 17.5 \mathrm{~g} \\ \text { Starch } & 1.50 \\ \text { Bacto Agar } & 17.0 \mathrm{~g}\end{array}$

$\mathrm{pH}=7.4$

How to manufacture:

Weighed as much as $38 \mathrm{~g}$ of MHA powder, then suspended in Erlenmeyer with distilled water, added piecemeal up to $1000 \mathrm{ml}$, heated to boiling while stirring until the soluble material is perfect and clear. Close the Erlenmeyer with cotton coated with aluminum foil. Sterilized in autoclave at $121^{\circ} \mathrm{C}$ at $2 \mathrm{~atm}$ for $15 \mathrm{~min}$ [5].

\section{Preparation of nutrient broth (NB)}

Composition:

$\begin{array}{ll}\text { Beef extract } & 3 \mathrm{~g} \\ \text { Bacto Peptone } & 5 \mathrm{~g}\end{array}$

Weighed as much as $8 \mathrm{~g}$ of NB powder, then suspended in Erlenmeyer with distilled water, added piecemeal up to $1000 \mathrm{ml}$, heated briefly while occasionally stirred until a clear solution is formed. Close the Erlenmeyer with cotton coated with aluminum foil. Sterilized in autoclave at $121^{\circ} \mathrm{C}$ at $2 \mathrm{~atm}$ for $15 \mathrm{~min}$ [5].

\section{Preparation of bacterial culture stock}

Culture of bacteria from the main strain taken with sterile ose needle by continuous method on nutrient surface to tilt, closed mouth tube reaction with cotton. Incubated for $18-24 \mathrm{~h}$ at $37^{\circ} \mathrm{C}$ [5].

\section{Preparation of inoculum bacteria}

Incubation bacteria taken with a sterile ose needle and then suspended into a tube containing $10 \mathrm{ml}$ of sterile, then homogenized with a vortex to obtain the same bacterial suspension turbidity with standard suspension turbidity of McFarland, this means that the concentration of bacterial suspension is $108 \mathrm{CFU}$ (colony-forming unit)/ml. After that, dilution with $0.1 \mathrm{ml}$ of bacterial culture $(108 \mathrm{CFU} / \mathrm{ml})$ was done, inserted into a sterile tube containing $9.9 \mathrm{ml}$ of NB solution, and homogeneously shaken the bacterial suspension was obtained with a concentration of $106 \mathrm{CFU} / \mathrm{ml}[6]$

\section{Preparation of extracted solutions with various concentrations} Concentrations weighed $5 \mathrm{~g}$ of dried ethanol extract from banana stone and then dissolved with $96 \%$ ethanol in a $10 \mathrm{ml}$ tiller up to the mark line. The concentration of extract is $500 \mathrm{mg} / \mathrm{ml}$. Subsequent dilutions were then made until an extract of $400 \mathrm{mg} / \mathrm{ml}, 300 \mathrm{mg} / \mathrm{ml}, 200 \mathrm{mg} / \mathrm{ml}$, $100 \mathrm{mg} / \mathrm{ml}, 90 \mathrm{mg} / \mathrm{ml}, 80 \mathrm{mg} / \mathrm{ml}, 70 \mathrm{mg} / \mathrm{ml}, 60 \mathrm{mg} / \mathrm{ml}, 50 \mathrm{mg} / \mathrm{ml}$, $40 \mathrm{mg} / \mathrm{ml}, 30 \mathrm{mg} / \mathrm{ml}, 20 \mathrm{mg} / \mathrm{ml}$, and $10 \mathrm{mg} / \mathrm{ml} \mathrm{[6]}$.

\section{Antibacterial activity test of banana stone fraction}

Bacterial suspension of $10^{-7} \mathrm{CFU} / \mathrm{ml}$ concentration was added to Petri dish and then added $18 \mathrm{ml}$ of MHA liquid medium $\left(45-50^{\circ} \mathrm{C}\right)$, then homogenized and silenced until medium solidified, then disc paper is immersed in a fraction solution starting from a concentration of $500 \mathrm{mg} / \mathrm{ml}$ to a dilution of $10 \mathrm{mg} / \mathrm{ml}$ and then inserting into a compacted medium and as a control of soaked disc paper in a DMSO solution. The Petri dish was closed and wrapped allowed to stand for 10-15 min and then incubated at $37^{\circ} \mathrm{C}$ for $18-24 \mathrm{~h}$, after which the bacterial growth inhibition diameter was measured in the clear region around the disc paper using a sliding range.

\section{Cellular metabolite leak test}

The suspension of test bacteria grown for $24 \mathrm{~h}$ by $10 \mathrm{ml}$ was centrifuged at a rate of $3.500 \mathrm{rpm}$ for $15-20 \mathrm{~min}$ to obtain bacterial cell deposits

The bacterial cell precipitate is then washed with phosphate buffer and repeated washing 2 times. The precipitate of the cell is then suspended into $10 \mathrm{ml}$ of phosphate buffer contacted with fraction at concentration 0 (control), 1, and 2 and incubated in shaker incubator (200 rpm) for $24 \mathrm{~h}$. After incubation, the bacterial suspension was centrifuged at a rate of $3.500 \mathrm{rpm}$ for $15-20$ minutes. So that, the supernatant and supernatant were then measured its absorbance by spectrophotometer at wavelengths 260 and $280 \mathrm{~nm}$ [7].

\section{Leakage test of metal ions}

Testing of leakage of ions is measured in the form of ions coming out of the bacterial cell membrane as a result of treatment with the extract of banana.

The ion leak test was performed on prepared bacterial pellets such as $\mathrm{Ca} 2+$ leakage measurement and $\mathrm{K}+$ proteins and nucleic acids. Leakage is expressed by measurements of metal ions presents in the test bacteria after contact with the extract at concentrations of 0 (control), 1 , and 2. The supernatant fluid was analyzed using AAS Thermo Elemental Solar MS type. The cell solution of contact with the fraction was taken to measure the content of the ions [8].

\section{RESULTS AND DISCUSSION}

\section{Result of plant identification}

Based on plant identification done in Herbarium Bogoriense Botanical Field of Biological Research Center, LIPI, Bogor, plant identity is M. balbisiana Colla, tribe of Musaceae.

\section{Result of fruit Banana stone fraction}

Result of maceration $1 \mathrm{~kg}$ simplicia of banana stone using n-hexane fraction and ethyl acetate fraction. The macerate was evaporate with a rotary evaporator and then evaporated to a thickened and weighed result, obtained by $15.3 \mathrm{~g}$ of $\mathrm{n}$-hexane and $31.7 \mathrm{~g}$ of ethyl acetate. The $\mathrm{n}$-hexane and ethyl acetate fractions were then used for antibacterial activity testing, leakage of cellular metabolite, and leakage of metal ions against SA, SE, and PA.

Antibacterial activity test result of banana fruit fractions against SA bacteria, Staphylococcus epidermis, and PA is shown in Fig. 1.

Based on Fig. 2, it can be concluded that the fraction of n-hexane has a less strong antibacterial activity so that the fraction of hexane banana stone inhibits the growth of SA bacteria, SE, and Propionibacterium acne less effective than ethyl acetate fractions that have strong antibacterial activity so that the ethyl acetate fraction of banana stone inhibits the growth of SA bacteria, SE, and P. acnes more effective. SA bacteria, SE, and $P$. acne are Gram-positive bacteria. The activity of an antimicrobial agent in inhibiting the growth or killing of microorganisms depends on the concentration of the antimicrobial [8]. 


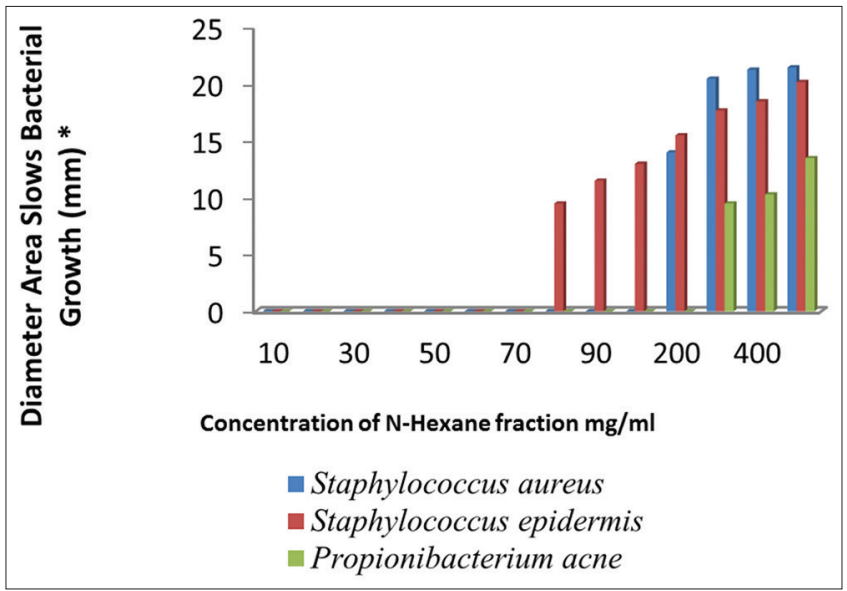

Fig. 1: Graph of antibacterial activity test result of n-hexane fraction of banana stone

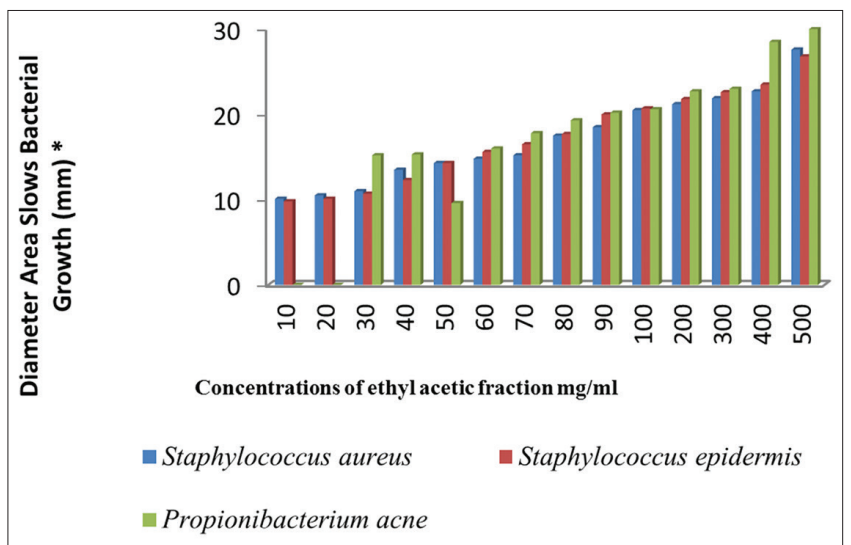

Fig. 2: Graph of antibacterial activity test of ethyl acetate fraction of banana stone

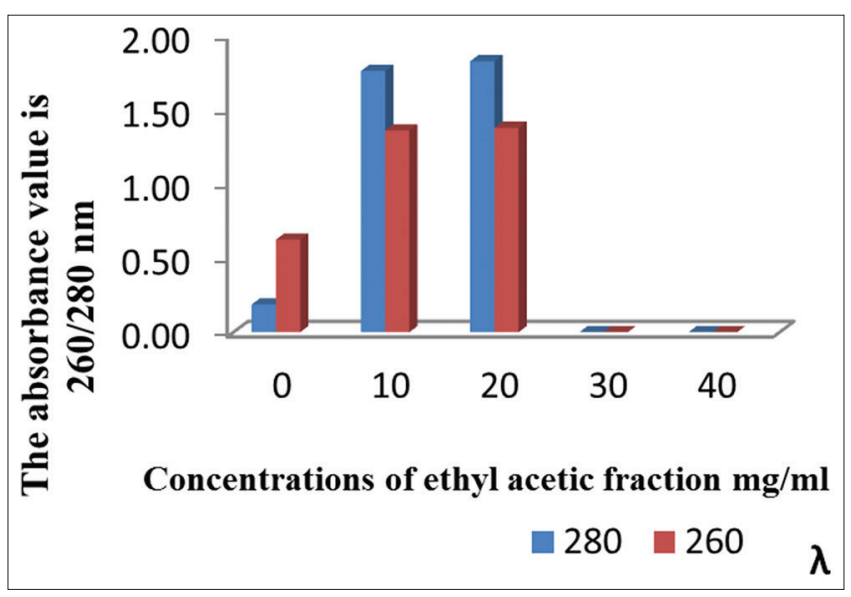

Fig. 3: Graph of cellular metabolite leakage test result of ethyl acetate fraction in Staphylococcus aureus bacteria

Cellular metabolite leak test results

The leakage of bacterial cell wall/membrane was analyzed by measuring absorbance at $260 \mathrm{~nm}$ (DNA) and $280 \mathrm{~nm}$ (nucleic acid) wavelengths.

Increased absorbance shown in Figs. 3-5 above that cell leakage in gram-positive bacteria such as Staphylococcus aureus, Staphylococcus

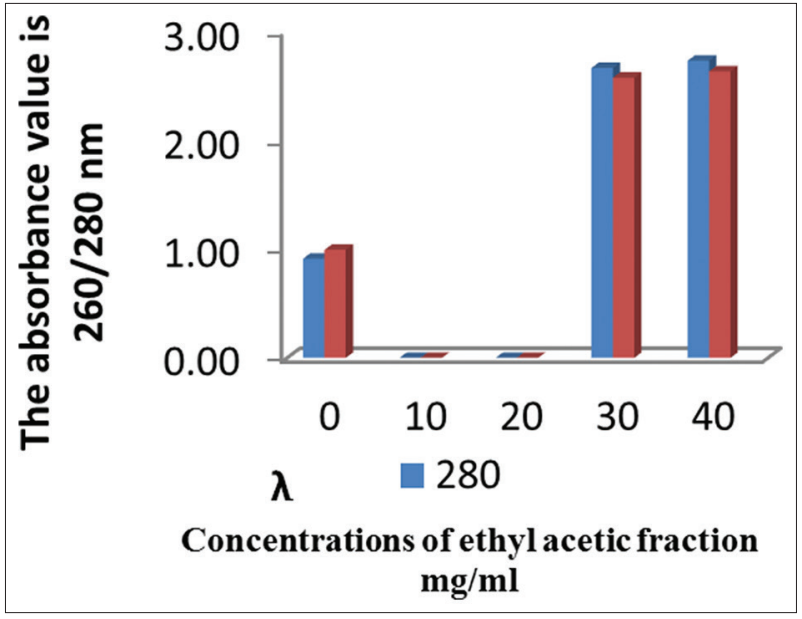

Fig. 4: Graph of cellular metabolite leakage test result of ethy acetate fraction in Staphylococcus epidermidis bacteria

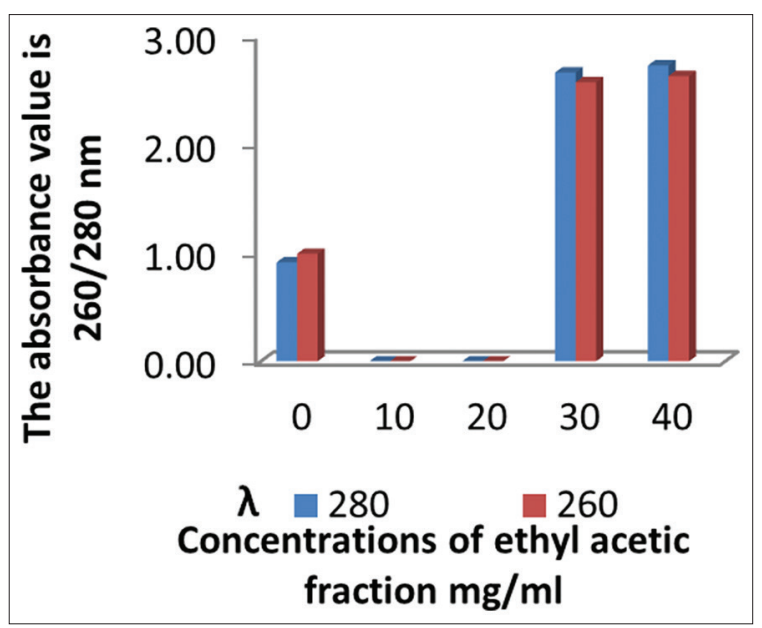

Fig. 5: Graph of leaf metabolite cellularity test results of ethyl acetate fraction in bacteria Propionibacterium acne

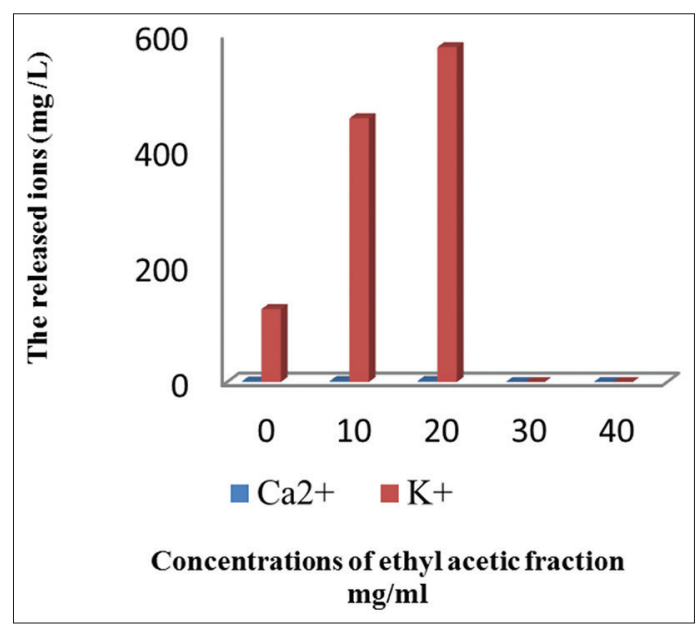

Fig. 6: Graph of test result of leakage of metal ions of ethyl acetate fraction in Staphylococcus aureus bacteria

epidermis and Propionibacterium acne due to ethyl acetate fraction of banana stone, a protein released higher than nucleic acid, meaning that the bacterial cell leaks more protein compounds than nucleic acids. 


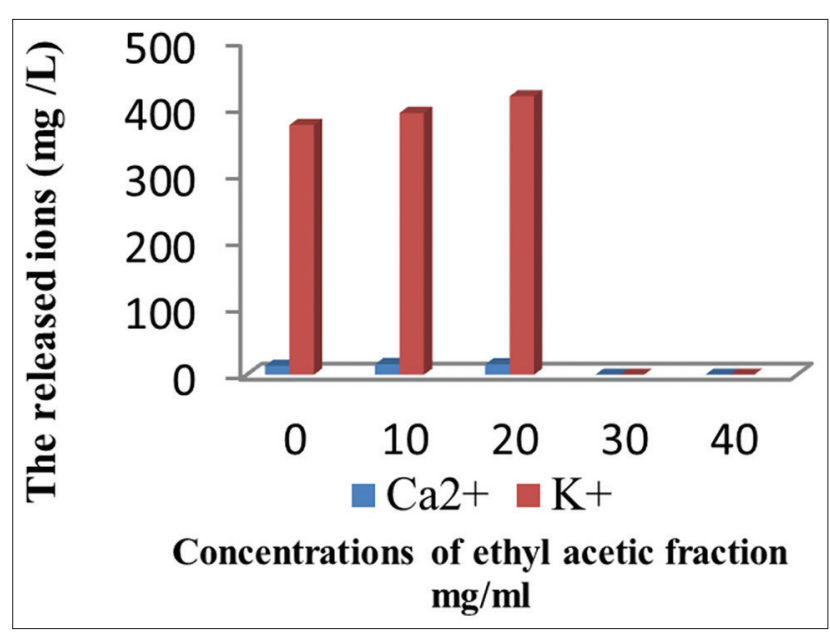

Fig. 7: Graph of leakage test results of metal ions of ethyl acetate fraction in bacterium Staphylococcus epidermidis

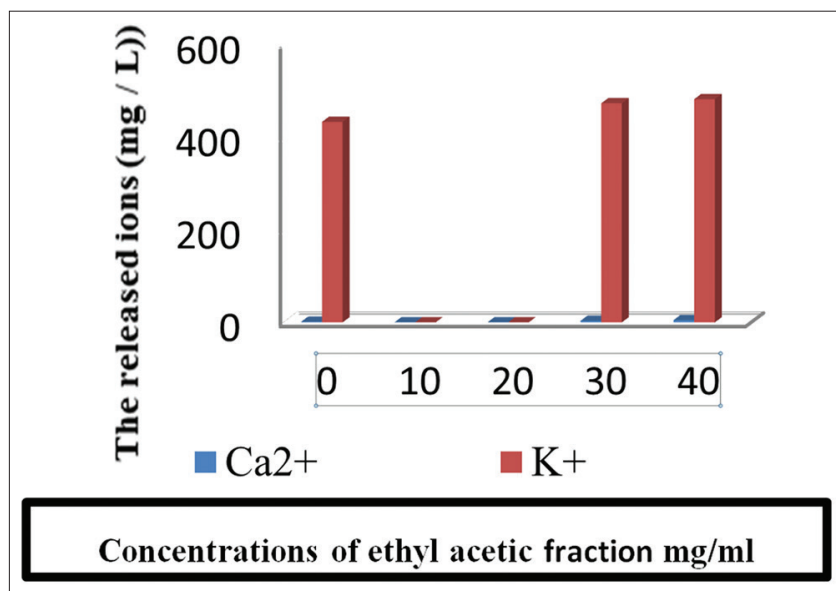

Fig. 8: Graph of leakage test results of metal ions of ethyl acetate fraction in Propionibacterium acnes bacteria

At $260 \mathrm{~nm}$, wavelengths can be detected purine, pyrimidine, and ribonucleotides, while at $280 \mathrm{~nm}$, wavelengths can be detected amino acids such as tyrosine and tryptophan [9].

In this study, cell leakage is caused by the interaction between antibacterial compounds of ethyl acetate fraction of banana stone with the outer membrane component of bacterial cell, especially component of phospholipid forming pore on bacterial cell membrane.

If the membrane pore enlarges due to phospholipid changes, larger molecules may be released from the cell membrane or the semi permeable nature of the membrane undergoes a change. Membrane permeability disorders in bacterial cells cause leakage of proteins and nucleic acids.

The leakage of bacterial cells due to the use of antibacterial compounds of the ethyl acetate fraction of banana stone can also be caused by damage to hydrophobic bonding components of cell membrane, such as proteins, phospholipids, and the solubility of hydrophilic and hydrophobic binding components [10].

\section{Test result of leakage of metal ions}

Figs. 6-8 show that metal ion leakage results in Staphylococcus aureus, Staphylococcus epidermis and Propionibacterium acne due to ethyl acetate fraction of stone bananas, $\mathrm{K}+$ ions released higher than $\mathrm{Ca} 2+$ ions. This suggests that the ethyl acetate fraction of a banana can cause leakage of cell membranes by releasing $\mathrm{Ca} 2+$ ions and proteins, nucleic acids and $\mathrm{K}+$ ions into the environment.. The $\mathrm{K}+$ ion has a role in activating cytoplasmic enzymes, maintaining turgor pressure, and regulating cytoplasmic $\mathrm{pH}$, while $\mathrm{Ca} 2+$ ions function to link lipopolysaccharide to Gram-negative bacteria cell wall [11]. In Gram-positive bacteria, Ca2+ ions connect the theophostic acid as a cell constituent.

The presence of such cations from the outer membrane causes the entry of antibacterial compounds into cells [12]. The damaged form of cell membranes is shown by the discharge of ingredients absorbed at a wavelength of $260 \mathrm{~nm}$, i.e. pentose, amino acids, or $\mathrm{K}+$ ions [13]

\section{CONCLUSION}

Based on the results and discussion above, it can be concluded that the fraction of banana stone which gives the most powerful antibacterial activity against test bacteria is ethyl acetate fraction, whereas the $\mathrm{n}$-hexane fraction still provides activity but in little concentration. The mechanism of action of inhibition of test bacteria on the fraction of banana stone through cell membrane destruction can be done only to the fraction of ethyl acetate.

The result of its mechanism of action is that leakage of cellular metabolites shows that cell leakage occurs more in protein compounds than nucleic acids, whereas the leakage of metal ions shows that cell leakage occurs more in $\mathrm{K}+$ ions than $\mathrm{Ca}+$ ions.

\section{ACKNOWLEDGMENTS}

On this occasion, the authors conveyed gratitude as much as possible to Mrs. Prof. Dr. Masfria, M.S., Apt., as the Dekan of the Faculty of Pharmacy University of North Sumatra who has provided facilities during the education period. Mr. Panal Sitorus, M.Si., Apt., and Mr. Prof. Dr. Dwi Suryanto, M.Sc., as mentors who have given time, guidance, and advice during the research with patience to the completion of the preparation of this thesis.

\section{REFERENCES}

1. Ministry of Health of the Republic of Indonesia. Indonesiam Herbal Pharmacopoeia. $1^{\text {st }}$ ed. Jakarta: Ministry of Health RI; 2011. p. 59.

2. Faculty of Pharmacy USU. Hepni Characterization of Simplicia and Antibacterial Activity Test of Banana Stone Ethanol Extract (Musa balbisiana Colla) Against Bacteria. Journal Pharmaceutical Biology. Medan: Faculty of Pharmacy USU; 2013. p. 18-23.

3. Ministry of Health of the Republic of Indonesia. Indonesiam Pharmacopoeia. $3^{\text {rd }}$ ed. Jakarta: Ministry of Health RI; 1979. p. 4-6, $855,896,1035$.

4. Lay BW. Microbial Analysis in Laboratory. Jakarta: PT, Raja Grafindo Persada; 1994. p. 67-71.

5. Difco Manual of Laboratories. Dehydrated Culture Media and Reagent for Mycrobiological and Clinical Laboratory Procedure. $9^{\text {th }}$ ed. Detroit Michigan: Difco Manual of Laboratories; 1977. p. 32-3.

6. Ministry of Health of the Republic of Indonesia. Materia Medika Indonesia. Vol. 4. Jakarta: Ministry of Health RI; 1955. p. 300-4, 306.

7. Chia ML, Preston JK, Wei CI. Antibacterial mechanism of allyl isothiocyanate. J Food Protec 2000;63:727-34.

8. Cox SD, Markham JL, Bell HC, Gustafson JE, Warnington JR, Wyllie SG. The mode of antibacterial action of the essential oil Melaleuca alterfolia (Tea Three Oil). J Appl Microbiol 2000;88:170-5.

9. Park SJ, Park HW, Park J. Inactivation kinetics of foods poisoning microorganisms by carbone dioxide and high hydrostatic pressure. J Food Sci 2003;68:976-81.

10. Kim JM, Marshal MR, Wei CI. Antibacterial activity of some essential components againts five food borne pathogens. J Agric Food Chem 1995:43:2839-45.

11. Nikaido H, Vaara M. Molecular basis of bacterial outer membrane permeability. Microbiol Rev 1985;49:1-32.

12. Stratford M. In: Robinson RK, Batt CA, Patel PD, editors. Traditional Preservatives-Organic Acids. Vol. 1. London: Encyclopedia of Food microbiology; 2000

13. Russell AD. In: Adrew MH, Russell AD, editor. Potential Sites of Damage in Microorganisms Exposes to Chemical or Physical Agent. London: The Revival of Injured Microbes, Academic Press; 1984. 